\title{
Implications of changing species definitions for conservation purposes
}

\author{
STEPHEN T. GARNETT and LES CHRISTIDIS
}

\section{Summary}

Concern has been expressed that failure to adopt phylogenetic or related species concepts will result in biodiversity loss. Here we describe how widespread adoption of such concepts may affect conservation administration and the social contract with elected governments that fund management of threatened species. We then review threatened species legislation, showing that most laws and international conventions avoid arguments over species' definitions altogether, thus negating arguments that such definitions should be changed to further species' conservation.

\section{Introduction}

The definition of species is at once one of the most fundamental and one of the most ephemeral concepts in biology. While the importance of taxonomy has been magnified since ratification of the Convention on Biological Diversity (Samper 2004), this has not helped end the search for a universal definition of species (see Padial and de la Riva 2006 for references). The initial purpose of Western taxonomy was to order biological diversity (Linnaeus 1758), and, until the twentieth century, the species was the first step in a hierarchy stretching up to kingdom, each step an accumulation of information on physical similarity expressed by the step before. In the twentieth century the foundations of this largely artificial structure were cemented in place by the Biological Species Concept (Mayr 1969). It was believed that the species was a mooring to which the confusion of life could be anchored.

Initially it had been hoped that genetics would provide definitive evidence of disputed species boundaries. Alas there was no elixir in genetic differentiation that separated species from other levels in the hierarchy - species became a stutter in the continuum of genetic diversity from gene to landscape rather than the single unarguable step. And the more that is known about genetic variation, the greater the confusion of statistical hierarchies that can be created with the information. The point at which phylogenetic hierarchies should be deconstructed into the category of species often seems to be a function of the choice of statistical models (e.g. Holder et al. 2005) and the portion of DNA (e.g. Rubinoff and Holland 2005) analysed.

This has affected species definitions. Many are in circulation (Mayr 1969, Wiley 1981, Paterson 1985, Ridley 1989, Templeton 1989, Nixon and Wheeler 1990, Committee on Scientific Issues in the Endangered Species Act 1995, Mallet 1995, Staley 1997, Blaxter 2004). Microbiologists, for instance, simply set an arbitrary level of overlap in DNA, 70\%, to define species. By this definition, chimpanzees and humans belong to a single species. As it is, only 6,000 species of bacteria have been described, none of which are threatened (Staley 1997, Ohren 2004). However, among complex organisms, the biological (BSC) and phylogenetic (PSC) species concept currently dominate debate (Isaac et al. 2005). The BSC is built around existing patterns of real or assumed reproductive behaviour, with forms being distinguished as species if there is a lack of free interbreeding (Mayr 1969). Thus, in birds, interspecific barriers can be porous (e.g. 
Grant and Grant 2002), with natural interspecific hybridization being relatively common, particularly among parapatric species (Randler 2006). Even intergeneric reproduction is commonplace in plants (Knobloch 1972). However, the different forms can be considered as species if mating is assortative. Where geographical isolation makes reproductive incompatibility impossible to prove, species rank is identified through comparison with similar sympatric species pairs (Mayr 1969).

The PSC deals with these same issues by recognizing species on the basis that populations need to be distinguishable only on differences in one taxonomic character and that there is "a parental pattern of ancestry and descent" (Cracraft 1989), even though the PSC populations sometimes meet, hybridize and become indistinguishable (Helbig et al. 2002, Gow et al. 2006). Although such an approach could simplify taxonomic decisions, it renders the concept in an operational, not theoretical, sense comparable to the typological concept of nineteenth-century systematists (Haffer 1992, Christidis and Boles 1994). The PSC is operationally and conceptually virtually indistinguishable from the subspecies rank of the BSC. The evolutionary species concept (ESC; Wiley 1978, Wiley and Mayden 2000, Peterson 2006, 2007), by which independent evolutionary trajectories are assessed on the basis of a largely subjective consideration of the degree of morphological and genetic divergence, has the same result. Since most subspecies were described in a pre-statistical era, the PSC or ESC merely add a formal framework not previously available (Remsen 2005). Thus a phylogenetic subspecies concept could indeed be useful, especially given the inconsistency with which such entities are currently defined (Zink 2003), but the application of the concept to species results merely in the loss of information about evolutionary relationships and degrees of separateness.

However, despite shortcomings of the PSC, it has proved popular in well-studied groups such as primates (Groves 2001) and, to a lesser extent, birds (e.g. Cracraft 1992, Robertson and Nunn 1998, Holdaway et al. 2001). This application of the PSC has led to an increase in the number of new "species", dubbed "taxonomic inflation" (Isaac et al. 2004). Because these new "species" inevitably have smaller distributions and populations than those from which they were derived, this greatly increases the number of species that meet IUCN Red List criteria for being threatened. Given these consequences, we think that two aspects of the discussion about species concepts warrant further comment: the implication that taxonomy can be used to advance conservation of threatened species, and the possible impact of adopting the PSC on conservation investment.

\section{Are conservation imperatives influencing taxonomy?}

Species are embedded in Western consciousness because, in any one place, most biological entities interbreed only with their own kind. The concept is widely understood; deriving from concepts arrived at through observation before formal Western taxonomy arose. We contend that public concern about biodiversity loss, which has resulted in political acceptance that biodiversity conservation is something in which public monies should be invested, is primarily concern for loss of species. The most recent evidence of this is acceptance of the IUCN Red Lists as measures of human progress towards meeting the Millennium Goals (BirdLife International 2007a). As Mace (in Marris 2007) observed, policy-makers and legislators believe strongly in the species concept whatever either taxonomists or conservation biologists may think about its merits. Furthermore we contend that this belief, and the concomitant investment in species conservation, assumes that the definition of species is based on objective principles and is not being manipulated to attempt to increase that investment.

Penhallurick and Wink (2004) contended that the main factor driving the splitting of albatross species in Robertson and Nunn (1998) was that conservation legislation in many countries where albatrosses breed and feed considers only species worthy of protection. Whatever the truth of this assertion, the perception that the PSC had been adopted for conservation objectives can damage both conservation and taxonomy. So too can statements that a failure to adopt the PSC 
is threatening species with small ranges (Hazevoet 1996), even if this is just a case of taxonomists being misunderstood (Sangster 2000). The rise in popularity of the PSC has certainly coincided not just with greater understanding of genetics but also with the fear of species extinction. Although it is obviously important that taxonomists and conservation biologists collaborate (Rojas 1992, Mace 2004), we fear that creating more species out of existing entities, inevitably with smaller ranges, could be perceived as a form of scientific dishonesty. If taxonomic changes are to be made for political reasons, then those elected to make political decisions have a right to participate in the debate.

This is partly because any shift to a PSC and a sudden surge in new species has implications for broader society beyond just conservation. Although the legal implications of changing species definitions may be surprisingly small (see below), each time the name of a species changes, or species boundaries are redefined, a huge bureaucratic process is triggered to update schedules, regulations, maps and publications. This has both transaction and opportunity costs, the former because substantial conservation monies are spent negotiating the new lists through the administrative processes, and the latter because those funds might have been available for genuine on-ground conservation. This is not to suggest the vigour of taxonomic endeavour should be reduced. The enthusiasm for the PSC that is driving taxonomic inflation in mammals and some other groups (Isaac et al. 2004) is in fact masking a surge in new species descriptions in groups such as the amphibians, most of which have been identified using conventional BSC taxonomic techniques (Padial and de la Riva 2006). Nor do we find fault with the systematic application of conventional techniques to reveal bird species hidden among existing entities (Watson 2005). Rather we advocate consistency in the amount of evidence required before new entities are created that warrant the attention of government investment. We believe that to expand lists of species en masse to reflect a new species concept about which only a subset of taxonomists agree, is to place the social commitment to threatened species conservation at risk for dubious benefit. Wholesale changes to species lists dissipate resources and political enthusiasm and have little benefit for conservation on the ground.*

\section{Taxonomy, legislation and Red Listing}

Curiously the bureaucratic activity that attends shifting taxa from subspecies to species actually influences very little with respect to the implementation of conservation legislation. If Robertson and Nunn (1998) did split the albatrosses for conservation reasons (Penhallurick and Wink 2004), they did so unnecessarily. In fact, for the most part, the people drafting international agreements or national legislation have carefully avoided defining "species" in any way that takes sides in the scientific debate (Table 1 ). None of the conventions or laws encountered in creating Table 1 state definitively that taxa below the level of species are to be ignored (although sometimes whole classes can be excluded, e.g. fish were deliberately omitted from the definition of vertebrates under the Territory Parks and Wildife Conservation Act in Australia's Northern Territory). Most explicitly include subspecies and populations. Although Annex five to the CITES convention (CITES 2007) does say species and subspecies are defined using the BSC, stating innocently that "'species' and 'subspecies' refer to the biological concept of a species, and do not require any further definition", it then explains how even populations can be included under its provisions. National legislation is equally inclusive, especially that written recently. The Philippine Wildlife Resources Conservation and Protection Act (RA 9147) 2001, for instance, specifically mentions that it includes subspecies, thus potentially easing Peterson's (2006) concern for several Philippine taxa not conventionally recognized as species. Among Western countries the legislation in which least guidance is given on definitions appears

\footnotetext{
"The debate has extended beyond scientific forums since this paper was accepted for publication; The Economist notes that it "behoves taxonomists to be honest. If they debase their currency, it will ultimately become valueless" (Anon 2007).
} 
Table 1. Definitions of species or their equivalent in a selection of international conventions and legislation aimed at species conservation. Countries were selected on the basis that legislation was readily available in English, to provide examples from all continents and across a spectrum of wealth.

\begin{tabular}{ll}
\hline Convention/Legislation (source) & Wording in relation to species \\
\hline International conventions
\end{tabular}

\section{International conventions}

Convention on Biological Diversity (www.biodiv.org)

Ramsar Convention on Wetlands (www.ramsar.org)

Convention on International Trade in Endangered Species of Wild Fauna and Flora (www.cites.org)

Convention on the Conservation of European Wildlife and Natural Habitat (conventions.coe.int)

\section{National legislation}

Australia

Environmental Protection and Biodiversity Conservation Act 1999 (www.austlii.edu.au)
Article 2: "Biological diversity" means the variability among living organisms from all sources including, inter alia, terrestrial, marine and other aquatic ecosystems and the ecological complexes of which they are part; this includes diversity within species, between species and of ecosystems

Article 1.1.a: "Migratory species" means the entire population or any geographically separate part of the population of any species or lower taxon of wild animals, a significant proportion of whose members cyclically and predictably cross one or more national jurisdictional boundaries

Criterion 6: A wetland should be considered internationally important if it regularly supports $1 \%$ of the individuals in a population of one species or subspecies of waterbird Criterion 7: ... a significant proportion of indigenous fish subspecies, species or families, life-history stages, species interactions and/or populations...

Criterion 9: ...it regularly supports $1 \%$ of the individuals in a population of one species or subspecies of wetlanddependent non-avian animal species

Article 1 (a): "Species" means any species, subspecies, or geographically separate population thereof

Annex 5 to Resolution Conf. 9.24: "Species" and

"subspecies" refer to the biological concept of a species, and do not require any further definition

"Geographically separate population" refers to parts of a species or a subspecies within particular geographical boundaries. This can also refer to populations or subpopulations, or, for the sake of convenience in certain cases, to "stocks"" as the term is understood in fisheries management

Article 4: Each Contracting Party shall take appropriate and necessary legislative and administrative measures to ensure the conservation of the habitats of the wild flora and fauna species, especially those specified in Appendices I and II

Appendix II includes the subspecies Puffinus assimilis baroli

Section 528: "species" means a group of biological entities that: (a) interbreed to produce fertile offspring; or (b) possess common characteristics derived from a common gene pool; and includes: (c) a sub-species; and (ca) for the purposes of Part ${ }_{13} A-a$ distinct population of such biological entities; and (d) except for the purposes of Part 13 $A-a$ distinct population of such biological entities that the Minister has determined, under section 517, to be a species for the purposes of this Act 
Table 1. Continued.

Convention/Legislation (source)
Canada
Species at Risk Act 2002 (laws.justice.gc.ca)

Chile

General Bases of the Environment 1994. Law (www.cochilco.cl)

China

Law of the People's Republic of China on the Protection of Wildlife 2004

(www.enviroinfo.org.cn)

England and Wales

Wildlife and Countryside Act 1981

(www.jncc.gov.uk)

India

Wildlife (Protection) Act 1972 (envfor.nic.in)

New Zealand

Wildlife Act 1953

Conservation Act 1987

(www.legislation.govt.nz)

Philippines

Wildlife Resources Conservation and

Protection Act (RA 9147) 2001

(www.grain.org)

South Africa

National Environmental Management:

Biodiversity Act 2004 (www.info.gov.za)

Thailand

Wild Animal Reservation and Protection

Act - BE. 25351992 (chanyakomol.com)

USA

Endangered Species Act 1973 (www.fws.gov)

Wording in relation to species

Section 2(I): "wildlife species" means a species, subspecies,

variety or geographically or genetically distinct population of animal, plant or other organism, other than a bacterium or virus, that is wild by nature

Title 1, Article 2: Biodiversity or biological diversity: the variability of organisms alive that form part of all terrestrial and aquatic ecosystems. It includes diversity within the same species, between species and between ecosystems

Wildlife protected under this Law refers to the species of terrestrial and aquatic wildlife which are rare or near extinction and the species of terrestrial wildlife which are beneficial or of important economic or scientific value

Part 1, Section 2: "wild animal" means any animal (other than a bird) which is ... living wild;"

"wild bird" means any bird of a kind which is ordinarily resident in or is a visitor to Great Britain in a wild state ... Provide[s] for the protection of [Wild animals, birds and plants]

Chapter 1. Section 2 (1): "animal" includes amphibians, birds, mammals, and reptiles, and their young, and also includes, in the cases of birds and reptiles, their eggs

Section 2 (I): Wildlife means any animal that is living in a wild state

Section 1, 2 (1): Animal means any member of the animal kingdom other than a human being

Ch.2.Section 5 (x): "Wildlife" means wild forms and varieties of flora and fauna, in all developmental stages, including those which are in captivity or are being bred or propagated

Sections f,h,i,o,w refer to "species and subspecies" of wildlife

Ch.I Part I (I): "species" means a kind of animal, plant or other organism that does not normally interbreed with individuals of another kind, and includes any sub-species, cultivar, variety, geographic race, strain, hybrid or geographically separated population

Section 4: "Wildlife" means all kinds of animals including terrestrial, aquatic, and winged animals as well as insects, which by nature are born and live in the forest or water

Section 3 (16): The term "species" includes any subspecies of fish or wildlife or plants, and any distinct population segment of any species or vertebrate fish of wildlife which interbreeds when mature

to be the Bern Convention and the compliant European legislation, at least from England and Wales. However, the Bern Convention schedules includes one subspecies among the protected "species", which implies that subspecies are contained within its definition of species.

Species do have higher prominence at the IUCN, which has devolved responsibility for defining the species concept among birds to BirdLife International, which holds firmly to the BSC (BirdLife International 2007b). However, threatened subspecies can be assessed under the 
IUCN criteria (IUCN 2001), and in the IUCN Red List (IUCN 2006) subspecies analyses are available for some mammals, plants, reptiles and insects. Subspecies assessments have not been provided for birds by the Red List Authority for birds, BirdLife International, primarily because there is a lack of resources to undertake a comprehensive assessment (Butchart 2005).

Nowhere, however, is the IUCN listing adopted into legislation and many wealthy countries have assessed the status of all subspecies of birds and listed those threatened under legislative schedules. Thus it tends to be the poorer countries, many of which are highly subspeciose, where subspecies assessment has not been undertaken. This leads to two related questions. First, would elevating subspecies to species under the PSC lead to official IUCN Red Listing? Second, given there is already provision for protecting subspecies under most local laws, will a lack of IUCN listing make a difference to investment in their conservation?

The answer to the first question is probably yes, in time, if comprehensive widely accepted taxonomic treatments using the PSC were available. As it is BirdLife recognizes that conventional revision of the taxonomy of places such as east Asian archipelagos will reveal more species than are currently recognized (BirdLife International 2007b).

The answer to the second question is far less certain. Although instability of species lists does make it difficult to understand macro-ecological processes, to identify concentrations of endemism with certainty, and to prioritize the allocation of conservation funds to hotspots (Isaac et al. 2004), conservation investment dollars in known hot spots based on analyses using the BSC are already stretched. Among birds, $20 \%$ of threatened species are not represented in protected areas (Rodrigues et al. 2004) and only $67 \%$ had received some conservation action during 2000-2004 (BirdLife International 2004). Conventional taxonomic revision is already adding to this burden as the BSC is applied more carefully. Universal application of the PSC could overwhelm the process yet protect entities that are only marginally different from those already being considered. Certainly BirdLife International is concerned that a full listing of subspecies or comprehensive PSC analysis could lead to diversion of limited conservation resources away from threatened full species, together with the assumption that a large proportion of threatened subspecies are likely to be benefiting by conservation action directed at species (S. Butchart in litt.).

In contrast, in those wealthy countries where subspecies are recognized as entities that ought to be conserved, the definition of taxa as subspecies has been no impediment to attracting political and financial support. A third of all funds allocated to threatened bird conservation in Australia in the period 1992-1999 were spent on threatened subspecies of species that had a status of Least Concern (Garnett et al. 2003). In the United Kingdom nearly all funds are spent on populations of species at the edge of their extensive European or Palaearctic ranges. The timber industry in north-western United States has been turned inside out on account of the northern subspecies of Spotted Owl Strix occidentalis caurina. Sadly, and tellingly for proponents of the PSC, not all investment in subspecies can been justified. Recent analyses of subspecies on the American mainland suggest that definitions of subspecies based on morphology alone are unreliable, and that substantial public funds have been invested in protecting entities whose taxonomic merit is questionable (e.g. Zink 2003).

\section{Conclusion}

For birds the BSC remains the most widely accepted taxonomic standard around the world. To promote the PSC, or indeed the ESC, on the basis that it is better for conservation is to risk alienating public trust in taxonomy as an objective science. Further there seems to be little practical merit in adopting the PSC for conservation purposes. National and international legislation has cannily avoided any definition that excludes entities that could be identified as species using the PSC. Although the global IUCN Red List has not so far considered all subspecies or distinct populations, adoption of the PSC in the IUCN Red List would incur substantial transaction and opportunity costs while having only marginal benefit for biodiversity 
conservation. As it is, countries that can afford to protect subspecies, or populations that are defined as species only using the PSC, will do so. Where funding is more limited, conservation efforts are likely to be concentrated on species that are defined conservatively.

\section{Acknowledgements}

This paper had its origins in a conversation with Nigel Collar and Ali Stattersfield of BirdLife International in 2002. The first author was also given advice by his host at the time, Andrew Balmford of the University of Cambridge Zoology Department. The paper has benefited in review from comments by Stuart Butchart, Gabriel Crowley, Adam Drucker, Lincoln Fishpool, Townsend Peterson, Peter Ryan, Van Remsen and an anonymous referee.

\section{References}

Anon (2007) Conservationists—and polar bears-should heed the lessons of economics. The Economist May 17th 2007. Downloaded from http://www.economist.com/ opinion/displaystory.cfm?story_id=9191545 on 23 July 2007.

BirdLife International (2004) State of the world's birds. Cambridge, U.K.: Birdlife International.

BirdLife International (2007a) Red List Index to become UN development indicator. Downloaded from http://www.birdlife. org/news/news/2007/o5/birds_become_ development_indicator.html on 5 May 2007.

BirdLife International (2007b) Taxonomy. Downloaded from http://www.birdlife. org/datazone/species/taxonomy.html on 5 May 2007.

Blaxter, M. L. (2004) The promise of a DNA taxonomy. Phil. Trans. R. Soc. B 359: 669-679.

Butchart, S. (2005) Tenth Grouse Specialist Group Workshop, Luchon, France, September 2005. Downloaded from http:// 72.14.253.104/search?q=cache:UlTyvoAa4QJ: www.gct.org.uk/gsg/doc/gsgminutesıoigs. doc+birdlife+not+list+subspecies\&hl $=$ en\& $\mathrm{gl}=\mathrm{au} \& \mathrm{ct}=\operatorname{clnk} \& \mathrm{~cd}=1$ on 16 January 2007.

Christidis, L. and Boles, W. E. (1994) The taxonomy and species of birds of Australia and its territories. RAOU Monograph 2. Melbourne: Royal Australasian Ornithologists Union.
Committee on Scientific Issues in the Endangered Species Act (1995) Science and the Endangered Species Act. Washington, DC: National Academy of Sciences.

CITES (2007) Convention on the International Trade in Endangered Species of Wild Fauna and Flora. Downloaded from www.cites.org/eng/res/og/o9-24R13.shtml on 18 January 2007.

Cracraft, J. (1989) Speciation and its ontology: the empirical consequence of alternative species concepts for understanding patterns and processes of differentiation. Pp. 28-59 in D. Otte and J. A. Endler, eds. Speciation and its consequences. New York: Sinauer Associates.

Cracraft, J. (1992) The species of the birds-ofparadise (Paradisaeidae): applying the phylogenetic species concept to a complex pattern of diversification. Cladistics 8: 1-43.

Garnett, S. T., Crowley, G. M. and Balmford, A. (2003) The costs and effectiveness of funding the conservation of Australian threatened birds. BioScience 53: 658-665.

Gow, J. L., Peichel, C. L. and Taylor, E. B. (2006) Contrasting hybridization rates between sympatric three-spined sticklebacks highlight the fragility of reproductive barriers between evolutionarily young species. Molecular Ecology 15: 739-752.

Grant, P. R. and Grant, B. R. (1992) Hybridization of bird species. Science 256 : 193-197. 
Groves, C. P. (2001) Primate taxonomy. Washington, DC: Smithsonian Institution Press.

Haffer, J. H. (1992) The history of species concepts and species limits in ornithology. Bull. Br. Ornithol. Club 112A: 39-52.

Hazevoet, C. J. (1996) Conservation and species lists: taxonomic neglect promotes the extinction of endemic birds, as exemplified by taxa from eastern Atlantic islands. Bird Conserv. Int. 6: 181-196.

Helbig, A. J., Knox, A. G., Parkin, D. T., Sangster, G. and Collinson, M. (2002) Guidelines for assigning species rank. Ibis 144: 518-525.

Holdaway, R. N., Worthy, T. H. and Tennyson, A. J. D. (2001) A working list of breeding bird species of the New Zealand region at first human contact. N. Z. J. Zool. 28: 119-187.

Holder, M. T., Lewis, P. O., Swofford, D. L. and Larget, B. (2005) Hastings ratio of the LOCAL proposal used in Bayesian phylogenetics. Syst. Biol. 54: 961-965.

Isaac, N. J. B., Mallet, J. and Mace, G. M. (2004) Taxonomic inflation: its influence on macroecology and conservation. Trends Ecol. Evol. 19: 464-469.

Isaac, N. J. B., Mace, G. M. and Mallet, J. (2005) Response to Agapow and Sluys: the reality of taxonomic change. Trends Ecol. Evol. 20: 280-281.

IUCN (2001) IUCN Red List categories and criteria. Version 3.1. Gland, Switzerland: IUCN Species Survival Commission.

IUCN (2006) 2006 IUCN Red List of threatened species. Downloaded from www.iucnredlist.org on 21 January 2007.

Knobloch, I. W. (1972) Intergeneric hybridization in flowering plants. Taxon 21: 97-103.

Linnaeus, C. (1758) Systema naturae per regna tria naturae, secundum classes, ordines, genera, species, cum characteribus, differentiis, synonymis, locis. Tenth edition.

Mallet, J. (1995) A species definition for the modern Synthesis. Trends Ecol. Evol. 10: 1-6.

Mace, G. (2004) The role of taxonomy in species conservation. Phil. Trans. R. Soc. B 359: 711-719.
Marris, E. (2007) Linnaeus at 300: The species and the specious. Nature 446: 250-253.

Mayr, E. (1969) Principles of systematic zoology. New York: McGraw-Hill.

Nixon, K. D. and Wheeler, Q. D. (1990) An amplification of the phylogenetic species concept. Cladistics 6: 211-223.

Ohren, A. (2004) Prokaryote diversity and taxonomy: current status and future challenges. Phil. Trans. R. Soc. B 359: 623-638.

Padial, J. M. and de la Riva, I. (2006) Taxonomic inflation and the stability of species lists: the perils of ostrich's behaviour. Syst. Biol. 55: 855-869.

Paterson, H. E. H. (1985) The recognition concept of species. Pp. 21-29 in E. S. Vrba, ed. Species and speciation. Transvaal Museum Monograph No. 4. Pretoria: Transvaal Museum.

Penhallurick, J. and Wink, M. (2004) Analysis of the taxonomy and nomenclature of the Procellariiformes based on complete nucleotide sequences of the mitochondrial cytochrome $b$ gene. Emu 104: 125-147.

Peterson, A. T. (2006) Taxonomy is important in conservation: a preliminary reassessment of Philippine species-level bird taxonomy. Bird Conserv. Int. 16: 155-173.

Peterson, A. T. (2007) Philippine bird taxonomy and conservation: a response to Collar. Bird Conserv. Int. in press.

Randler, C. (2006) Behavioural and ecological correlates of natural hybridization in birds. Ibis 148: 459-467.

Remsen, J. V. Jr (2005) Pattern, process, and rigor meet classification. Auk 22: 403-413.

Ridley, M. (1989) The cladistic solution to the species problem. Biol. Philos. 4: 1-16.

Robertson, C. J. R. and Nunn, G. B. (1998) Towards a new taxonomy for albatrosses. Pp. 13-19 in G. Robertson and R. Gales, eds. Albatross biology and conservation. Sydney: Surrey Beatty.

Rodrigues, A. S. L., Andeman, S. J., Bakarr, M. I., Boitani, L., Brooks, T. M., Cowling, R. M., Fishpool, L. D. C., da Fonseca, G. A. B., Gaston, K. J., Hoffmann, M., Long, J. S., Marquet, P. A., Pilgrim, J. D., Pressey, R. L., Schipper, J., Sechrest, W., Stuart, S. N., Underhill, L. G., Waller, R. W. and Watts, M. E. J. (2004) Effectiveness of the global 
protected area network in representing species diversity. Nature 428: 640-643.

Rojas, M. (1992) The species problem and conservation: what are we protecting? Conserv. Biol. 6: 170-178.

Rubinoff, D. and Holland, B. S. (2005) Between two extremes: mitochondrial DNA is neither the panacea nor the nemesis of phylogenetic and taxonomic inference. Syst. Biol. 54: 952-961.

Samper, C. (2004) Taxonomy and environmental policy. Phil. Trans. R. Soc. B 359: $721-728$.

Sangster, G. (2000) Taxonomic stability and avian extinctions. Conserv. Biol. 14: 579-581.

Staley, J. T. (1997) Biodiversity: are microbial species threatened? Opin. Biotechnol. 8: 340-345.

Templeton, A. (1989) The meaning of species and speciation: a genetic perspective.
Pp. 3-27 in D. Otte and J. Endler, eds. Speciation and its consequences. Massachusetts: Sinauer Associates.

Watson, D. M. (2005) Diagnosable versus distinct: evaluating species limits in birds. BioScience 55: 60-68.

Wiley, E. (1981) Phylogenetics: The theory and practice of phylogenetic systematics. New York: Wiley.

Wiley, E. O. (1978) The evolutionary species concept reconsidered. Syst. Zool. 27: 17-26.

Wiley, E. O. and Mayden, R. L. (2000) The evolutionary species concept. Pp. 70-89 in Q. D. Wheeler and R. Meier, eds. Species concepts and phylogenetic theory: $A$ debate, 200o. New York: Columbia Press.

Zink, R. M. (2003) The role of subspecies in obscuring avian biological diversity and misleading conservation policy. Proc. $R$. Soc. Lond. B 271: 561-564.

\section{S. T. GARNETT*}

School for Environmental Research, Charles Darwin University, Darwin NT, ogog Australia.

\section{CHRISTIDIS}

Australian Museum, Sydney, NSW, 2010 Australia and Department of Genetics, University of Melbourne, Parkville, Vic3052, Australia.

*Author for correspondence.e-mail: stephen.garnett@cdu.edu.au 